\title{
IMPLEMENTASI KEBIJAKAN PROGRAM GOTONG ROYONG DI KECAMATAN SEBERANG ULU 1 KOTA PALEMBANG PROVINSI SUMATRA SELATAN
}

\author{
Oleh \\ Galih Andawisa ${ }^{1}$, \\ Kusworo², Ali Hanafiah Muhi $^{3}$ \\ 1) Institut Pemerintahan Dalam Negeri \\ Program Magister Terapan Studi Pemerintahan Daerah Institut Pemerintahan Dalam Negeri \\ galihandawisa.ga@gmail.com \\ 2,3) Institut Pemerintahan Dalam Negeri
}

\section{ABSTRACT \\ MUTUAL ASSISTANCE IMPLEMENTATION POLICY PROGRAM IN SUB-DISTRICT SEBERANG ULU 1 PALEMBANG CITY SOUTH SUMATRA PROVINCE}

$P^{2}$ eople awareness to the environment at Palembang City for the last 2 years cause to a minimum function of city river. Starting this point, Palembang Government legalized Mayor Regulation Number 14 in 2019 about Performing Gotong Royong on city, district, independent and neighborhood level. For the last 5 years, regulation has changed every year to maximalize gotong royong in society. They found obstacles like less facilities, less information received, and more. Thus, author interested to analyze Implementation of Gotong Royong Program Policy at Seberang Ulu 1 District, Palembang City, South Sumatra Province.

This research aims to determine the implementation of mutual assistance program policies in the District of Seberang Ulu 1 Palembang City. The research design used is qualitative research with descriptive methods and inductive approaches. Data collection techniques are done by interview, observation, and documentation. This study uses the main theory of Gratitude which is seen from 4 dimensions, namely Environment, Targer Group, Programs, Implementing Elements.

This research program has discussed the program of mutual cooperation policy implementation in the District of Seberang Ulu 1 Palembang City which has been running according to the procedures made in the regulations related to the implementation of the mutual cooperation program which has not been optimal. In some cases, supporting factors in the form of funds/budgets specifically provided from the APBD and FKPD of Palembang City which fell directly in the implementation of mutual assistance, In addition there are also several inhibiting factors described related to community participation to participate in the implementation of mutual cooperation, still need discipline of government officials, and inadequate infrastructure and infrastructure.

Keywords: implementation, policy, mutual assistance

\section{ABSTRAK}

$\mathrm{K}$ esadaran masyarakat akan lingkungan di Kota Palembang selama dua tahun terakhir mengakibatkan kurang maksimal fungsionalisasi sungai. Berangkat dari fenomena ini, 
Pemerintah Kota Palembang mengeluarkan Peraturan Wali Kota Palembang No. 14 Tahun 2019 tentang Pelaksanaan Gotong Royong Tingkat Kota, Kecamatan, Mandiri dan RT/RW. Selama 5 tahun terakhir, peraturan tersebut mengalami perubahan dari tahun ke tahun untuk memaksimalkan gotong royong di tengah masyarakat. Ditemui kendala seperti kurangnya sarana prasarana yang mendukung kegiatan, sedikitnya sosialisasi yang diterima masyarakat, dan kendala lain. Untuk itu, penulis tertarik meneliti tentang Implementasi Kebijakan Program Gotong Royong di Kecamatan Seberang Ulu 1 Kota Palembang Provinsi Sumatra Selatan.

Penelitian ini bertujuan untuk mengetahui implementasi kebijakan program gotong royong di Kecamatan Seberang Ulu 1 Kota Palembang dengan berdasar pada teori Syukur. Desain penelitian yang digunakan adalah penelitian kualitatif dengan metode deskriptif dan pendekatan induktif. Teknik pengumpulan data yang dilakukan dengan wawancara, observasi, dan dokumentasi. Penelitian ini menggunakan teori utama Syukur yang dilihat dari empat dimensi yaitu Lingkungan, Target Group, Program, Unsur Pelaksana.

Hasil penelitian ini disimpulkan bahwa implementasi kebijakan program gotong royong di Kecamatan Seberang Ulu 1 Kota Palembang sudah berjalan sesuai prosedur sebagaimana yang diatur dalam peraturan terkait pelaksanaan program gotong royong namun belum optimal. Dalam pelaksanaannya terdapat beberapa faktor pendukung, yakni dana/anggaran yang disediakan khusus dari APBD dan FKPD Kota Palembang yang turun langsung dalam pelaksanaan gotong-royong, Selain itu juga terdapat beberapa faktor penghambat, yakni masih kurangnya kesadaran masyarakat untuk ikut serta dalam pelaksanaan gotong royong, masih kurangnya kedisiplinan aparat pemerintah, dan sarana dan prasarana yang belum memadai.

Kata kunci: implementasi, kebijakan, gotong royong

\section{PENDAHULUAN}

$\mathrm{K}_{\mathrm{t}}^{\mathrm{e}}$ ebersihan merupakan hal yang tak terpisahkan dari kehidupan manusia dan merupakan unsur yang fundamental dalam ilmu kesehatan dan pencegahan. yang dimaksud dengan kebersihan lingkungan adalah menciptakan lingkungan yang sehat sehingga tidak mudah terserang berbagai penyakit sepertidiare,demamberdarah, muntaber dan lainnya. Hal ini dapat dicapai dengan menciptakan suatu lingkungan yang bersih indah dan nyaman. Di Indonesia, masalah kebersihan lingkungan selalu menjadi perdebatan dan masalah yang berkembang. Kasus-kasus yang menyangkut masalah kebersihan lingkungan setiap tahunnya terus meningkat. Problem tentang kebersihan lingkungan yang tidak kondusif dikarenakan masyarakat selalu tidak sadar akan hal kebersihan lingkungan.

Kesadaran masyarakat sangat diperlukan dalam menjaga kebersihan lingkungan, dengan kesadaran masyarakat juga menunjukkan adanya kepedulian masyarakat terhadap lingkungan. Dan melalui kesadaran dalam menjaga kebersihan lingkungan itu merupakan suatu bentuk kerja sama masyarakat dengan pemerintah. Kesadaran masyarakat dalam menjaga lingkungan dapat dilakukan dengan berbagai macam cara seperti gotong royong dalam kegiatan kebersihan lingkungan, dan sebagainya.

Adanya otonomi daerah yang merupakan hak, wewenang dan kewajiban daerah otonom untuk mengatur dan mengurus sendiri urusan pemerintahan dan kepentingan masyarakat setempat dalam Sistem Negara Kesatuan Republik Indonesia maka dalam pelaksanaannya Pemerintah Kota Palembang berupaya mewujudkan visi Kota Palembang, yakni EMAS Darussalam yang mengandung makna Elok, Madani, Aman, dan Sejahtera sedang Darussalam mengandung makna Kota Palembang menjadi kota yang Aman, Damai, Tenteram, Makmur dan Sejahtera serta adanya harmoni antara kehidupan manusia dan alam. 
Di dalamnya terdapat nilai yang luhur, sehingga harus tetap ada dan terus menjadi bagian dari kehidupan masyarakat yang menjunjung tinggi nilai kemanusiaan. Setiap pekerjaan dilakukan secara bersamasama tanpa melihat kedudukan seseorang tetapi lebih melihat pada keikutsertaan masyarakat dalam suatu kegiatan yang ada di masyarakat. Gotong royong yang telah ada di Indonesia dari dulu tentunya tidak hanya ada di satu daerah, namun menyebar di semua wilayah di Indonesia.

Pada 2015 Pemerintah Kota Palembang mulai melaksanakan program gotong royong kemudian sekitar setahun pelaksanaan kegiatan tersebut dinilai cukup baik, maka pada 2016 Pemerintah Kota Palembangdalam hal ini Wali Kota Palembang menetapkan kebijakan yang tertuang dalam Keputusan Wali Kota Palembang No. 211 Tahun 2016 tentang Petunjuk Teknis Pelaksanaan Gotong Royong dan Pembentukan Koordinator Wilayah, Tim Pengawas dan Evaluasi Gotong Royong kemudian keputusan ini diubah menjadi Keputusan Wali Kota Palembang No. 405 Tahun 2016 tentang perubahan kedua dari Keputusan Wali Kota Palembang No. 211 Tahun 2016.

Dengan ditetapkannya Peraturan Wali Kota Palembang No. 14 Tahun 2019 yang mengatur tentang program gotong royong diharapkan mampu meningkatkan semangat dan kepedulian masyarakat Kota Palembang melalui teladan yang dicontohkan oleh para pejabat khususnya di lingkungan Kota Palembang dalam menjaga kebersihan Kota Palembang selain itu meningkatkan budaya gotong royong yang merupakan nilai moral dan ciri khas bangsa Indonesia sejak zaman dahulu sebagai wujud pengamalan dari sila ketiga Pancasila "Persatuan Indonesia" yang selama ini dirasa sudah memudar.

Dalam pelaksanaannya, program gotong royong tidak mudah untuk dapat diterima masyarakat. Oleh sebab itu dibutuhkan komitmen yang kuat dari Wali
Kota Palembang beserta perangkatnya untuk terus mengajak dan menjadi teladan dalam menjaga kebersihan Kota Palembang sehingga mampu memotivasi masyarakat untuk memiliki kesadaran dalam menjaga kebersihan lingkungan.

Padahal pegawai kecamatan telah berusaha untuk menumbuhkan kesadaran masyarakat dengan harapan masyarakat bisa tergerak untuk bersama-sama ikut serta dalam kegiatan gotong royong tersebut, hal ini dibenarkan oleh camat pada saat peneliti melakukan observasi di lapangan pada 10 Desember 2019.

Kegiatan ini merupakan kegiatan yang rutin dilaksanakan guna meningkatkan kebersihan di seluruh Kota Palembang dan menyukseskan visi Palembang EMAS. Di Kota Palembang, ketersediaan sarana dan prasarana kebersihan masih belum cukup memadai antara lain seperti TPS yang masih minim. Berdasarkan data dari Kecamatan Seberang Ulu 1 Tahun 2019, Jumlah TPS yang ada di Kecamatan Seberang Ulu 1 Tahun 2019 hanya berjumlah 13 TPS, kemudian untuk kendaraan pengangkut sampah seperti dump truk dan motor kaisar masingmasing hanya berjumlah satu unit.

Memperoleh bagaimana mengatasi faktor pendukung dan penghambat dalam implementasi Kebijakan Program Gotong Royong yang sesuai di Kecamatan Seberang Ulu 1 Kota Palembang. Manfaat Penelitian.

\section{KAJIAN TEORETIS}

Fokus penelitian ini membahas terkait implementasi kebijakan tentang gotong royong. Teori yang digunakan ialah Edward III sedangkan penulis gunakan ialah Syukur. Tahun 2016, Lia Okta Ayu melakukan penelitian dalam rangka penulisan tesis yang berjudul "Implementasi Pemahaman dan Sikap Pemuda terhadap Nilai Gotong Royong untuk Pembangunan di Desa Semarang Jaya Kecamatan Air Hitam Kabupaten 
Lampung Barat". Hal ini dapat dilihat dari hasil pengujian data yang dilakukan bahwa menunjukkan tidak relevannya kegiatan gotong royong tersebut terhadap kemajuan atau pembangunan desa. Dalam penelitian masih banyak pemuda yang paham terhadap nilai gotong royong tersebut tetapi pemuda tidak memiliki sikap untuk melaksanakan kegiatan gotong royong tersebut.

Faktor yang memengaruhi pemuda memiliki sikap pemahaman yang tinggi tetapi tidak melaksanakan nilai-nilai di dalamnya karena pemuda memilih untuk bekerja untuk membantu kebutuhan keluarga dari pada untuk mengikuti kegiatan gotong royong. Faktor lain yang menyebabkan yaitu karena pemuda malas dan merasa bukan tanggung jawab mereka. Dan ada yang berpikir bahwa kegiatan gotong royong tersebut tidak memiliki sanksi yang tegas. Perbedaan terletak pada lokasi penelitian dan pendekatan yang digunakan, penulis menggunakan pendekatan Kuantitatif dengan metode deskriptif dengan teknik pengumpulan data menggunakan metode angket, studi pustaka, observasi dan wawancara dan dalam penelitian ini menggunakan kualitatif dengan metode deskriptif dan pendekatan induktif.

Teori yang peneliti gunakan ialah Edward III sedangkan penulis gunakan ialah Syukur. Tahun 2016, Miftah Yoga Aryana melakukan penelitian dalam rangka penulisan tesis yang berjudul "Implementasi Kebijakan Gotong Royong dan Peduli Sosial pada Tradisi Nyadran Dukuh Wonorejo, Desa Bulusan, Kecamatan Karangdowo, Kabupaten Klaten". Berdasarkan uraian dari bab demi bab yang telah peneliti kemukakan di atas, maka peneliti bisa mengambil beberapa simpulan.

Tetapi pada tataran yang lain hal tersebut justru akan menyelewengkan tujuan yang hendak dicapai oleh kebijakan yang telah ditetapkan. Perintah yang diberikan dalam pelaksanaan komunikasi haruslah konsisten dan jelas. Karena jika perintah yang diberikan sering berubah-ubah, maka dapat menimbulkan kebingungan bagi pelaksana di lapangan. Sebagaimana yang dijelaskan pada paragraf sebelumnya, staf merupakan sumber daya utama dalam implementasi kebijakan.

Kegagalan yang sering terjadi dalam implementasi, salah satunya disebabkan oleh staf atau pegawai yang tidak cukup memadai, mencukupi, ataupun tidak kompeten dalam bidangnya. Disposisi atau sikap dari pelaksana kebijakan adalah faktor yang penting dalam pendekatan mengenai pelaksanaan suatu kebijakan publik. Jika pelaksanaan suatu kebijakan ingin efektif, maka para pelaksana kebijakan tidak hanya harus mengetahui apa yang akan dilakukan tetapi juga harus memiliki kemampuan untuk melaksanakannya, sehingga dalam praktiknya tidak terjadi bias. Jika para pelaksana bersikap baik terhadap suatu kebijakan tertentu, dan hal ini berarti adanya dukungan, kemungkinan besar mereka melaksanakan kebijakan sebagaimana yang diingini oleh pembuat kebijakan.

\section{Konsep Gotong Royong}

Setiap bangsa dalam sebuah negara pasti memiliki kebudayaan yang khas yang membedakan dari bangsa lainnya. Seperti bangsa Indonesia yang dikenal ramah dan menjunjung tinggi nilai luhur kebudayaan yang diwariskan oleh generasi terdahulu. Salah satu budaya yang masih dipegang oleh masyarakat Indonesia yaitu budaya gotong royong. Budaya yang mengedepankan kepentingan umum dibandingkan kepentingan pribadi.

Di mana setiap orang bahu membahu membantu meringankan beban orang lain yang sedang membutuhkan pertolongan. “ Dalam bahasa Jawa kata saiyeg saeko proyo atau satu gerak satu kesatuan usaha memiliki makna yang amat dekat untuk melukiskan kata royong ini». Kemudian menurut Sajogyo dan Pudjiwati megungkapkan "gotong royong adalah aktivitas bekerja sama 
antara sejumlah besar warga desa untuk menyelesaikan suatu proyek tertentu yang dianggap berguna bagi kepentingan umum». Selain itu pendapat lain diungkapkan oleh Pasya bahwa 'gotong royong sebagai bentuk integrasi banyak dipengaruhi oleh rasa kebersamaan antarwarga komunitas yang dilakukan secara sukarela tanpa adanya jaminan berupa upah atau pembayaran dalam bentuk lainnya'.

Berdasarkan pernyataan di atas, dapat ditarik simpulan mengenai pengertian dari gotong royong merupakan kegiatan yang dilakukan secara bersama-sama dengan tujuan menolong secara sukarela. Beberapa daerah di Indonesia di antaranya masih ada yang mempertahankan budaya gotong royong. " Kedua, memperkuat dan mempererat hubungan antarwarga dan komunitas serta dengan kerabatnya yang telah bertempat tinggal di tempat lain. Ketiga, menyatukan seluruh warga komunitas yang terlibat di dalamnya».

Jenis gotong royong ini berupa tolong menolong yang terbatas di dalam lingkungan beberapa keluarga tetangga atau satu dukuh, misalnya dalam hal kematian, perkawinan, mendirikan rumah dan sebagainya. Gotong royong semacam ini terlihat sepanjang masa, bersifat statis karena merupakan suatu tradisi saja, merupakan suatu hal yang diterima secara turun temurun dari generasi ke generasi berikutnya. Adat untuk meminta bantuan tetangga guna pekerjaanpekerjaan serupa itu di daerah KaranganyarKebumen dikonsepsikan sebagai suatu hal yang berbeda dengan sambatan, dan disebut dengan istilah lain, yaitu guyuban. Namun dalam kerja bakti ini harus bisa membedakan antara kerja bakti yang bersifat sukarela dan kerja bakti yang bersifat perintah.

Secara umum, pengertian gotong royong dapat ditemukan dalam kamus besar bahasa indonesia yang menyebutnya sebagai "bekerja bersama-sama atau tolongmenolong, bantu-membantu». Sementaraitu, dalam perspektif antropologi pembangunan, oleh Koentjaraningrat gotong royong didefinisikan sebagai pengerahan tenaga manusia tanpa bayaran untuk suatu proyek atau pekerjaan yang bermanfaat bagi umum atau yang berguna bagi pembangunan. Partisipasi aktif tersebut bisa berupa bantuan yang berwujud materi, keuangan, tenaga fisik, mental spiritual, keterampilan, sumbangan pikiran atau nasihat yang konstruktif, sampai hanya berdoa kepada Tuhan. Secara konseptual, gotong royong dapat diartikan sebagai suatu model kerja sama yang disepakati bersama.

Kegiatan gotong royong kerja bakti biasanya dilakukan untuk mengerjakan sesuatu hal yang sifatnya kepentingan umum, yang dibedakan antara gotong royong atas inisiatif warga dengan gotong royong yang dipaksakan. Dalam perspektif sosio budaya, nilai gotong royong adalah semangat yang diwujudkan dalam bentuk perilaku atau tindakan individu yang dilakukan tanpa pamrih untuk melakukan sesuatu secara bersama-sama demi kepentingan bersama atau individu tertentu. Gotong royong merupakan ciri budaya bangsa indonesia yang berlaku secara turun-temurun sehingga membentuk perilaku sosial yang nyata dalam tata nilai kehidupan sosial. Nilai tersebut menjadikan kegiatan gotong royong selalu terbina dalam kehidupan komunitas sebagai suatu warisan budaya yang patut untuk dilestarikan.

\section{Kebersihan}

Kebersihan merupakan keadaan yang higienis, terbebas dari kotoran, kebersihan merujuk pada keimanan. Kebersihan ialah upaya manusia untuk memelihara diri dan lingkungan dari segala yang kotor dan keji dalam rangka mewujudkan dan melestarikan kehidupan yang sehat dan nyaman. kebersihan merupakan syarat bagi terwujudnya kesehatan, kemudian menjadi salah satu faktor yang dapat memberikan kebahagiaan. Kebersihan iyalah salah satu 
tanda dari keadaan higienis yang baik. Untuk menjaga kebersihan, hal pertama yang harus dilakukan adalah jangan membuang sampah di lingkungan sekitar kita.

\section{METODE PENELITIAN}

Data primer dalam penelitian ini diperoleh dari hasil wawancara dengan informan». Dalam penelitian ini peneliti akan melaksanakan wawancara tentang pelaksanaan kepada informan yang sudah ditentukan oleh penulis. "Data sekunder dalam penelitian ini diperoleh dari penelaahan bahan-bahan bacaan dan literatur lainnya yang berkaitan dengan fokus penelitian berupa buku-buku, peraturan laporan, serta dokumen yang telah tersedia yang berhubungan dengan implementasi kebijakan program gotong royong di Kecamatan Seberang Ulu 1 di Kota Palembang. Sehingga dalam pelaksanaan suatu penelitian untuk mendapatkan data yang terkait dengan fokus penelitian maka peneliti terlebih dahulu harus mampu menentukan subjek penelitian.

Bungin menyatakan informan penelitian adalah »subjek yang memahami informasi objek penelitian sebagai pelaku maupun orang lain yang memahami objek penelitian". Peneliti benar-benar "buat" informasi tentang objek penelitian.

\section{Informan dan Penelitian}

Data primer dalam penelitian ini diperoleh dari hasil wawancara dengan informan". "Dalam penelitian ini peneliti akan melaksanakan wawancara tentang pelaksanaan kepada informan yang sudah ditentukan oleh penulis. Data sekunder dalam penelitian ini diperoleh dari penelaahan bahan-bahan bacaan dan literatur lainnya yang berkaitan dengan fokus penelitian berupa buku-buku, peraturan laporan, serta dokumen yang telah tersedia yang berhubungan dengan implementasi kebijakan program gotong royong di Kecamatan Seberang Ulu 1 di Kota Palembang. Bungin menyatakan informan penelitian adalah "subjek yang memahami informasi objek penelitian sebagai pelaku maupun orang lain yang memahami objek penelitian». Sugiyono mengemukakan pengumpulan data merupakan "langkah yang paling strategis dalam penelitian, karena tujuan utama dari penelitian adalah mendapatkan data».

Wawancara dapat dilakukan dengan menggunakan banyak cara, baik dengan cara tatap muka maupun dengan menggunakan alat bantu komunikasi serta wawancara ada yang terstruktur maupun tidak terstruktur.

Oleh karena itu dalam penelitian ini penulis mengumpulkan data berupa buku, surat, profil daerah dan peraturan perundang-undangan yang ada relevansinya dengan permasalahan yang dibahas dalam penelitian ini terkait dengan implementasi kebijakan program gotong royong di Kecamatan Seberang Ulu 1 di Kota Palembang.

\section{Lapangan}

Gunawan menyatakan bahwa "istilah observasi diarahkan pada kegiatan memperhatikan secara akurat, mencatat fenomena yang muncul dan mempertimbangkan hubungan antar aspek dalam fenomena tersebut». Selanjutnya Gunawan menjelaskan bahwa "observasi dalam rangka penelitian kualitatif harus dalam konteks alamiah".

Berdasarkan pendapat tersebut dapat dikatakan bahwa observasi merupakan teknik pengumpulan data dengan mengadakan pengamatan langsung terhadap gejala-gejala dari objek yang diteliti. Pengamatan yang dilakukan oleh peneliti dilakukan baik dalam keadaan situasi yang sebenarnya maupun situasi khusus yang diadakan, dalam hal ini peneliti selalu mengaitkan antar dua hal yaitu informasi dan konteksnya. Informasi adalah apa yang 
ada dan terjadi, sedangkan konteksnya merupakan hal-hal yang berkaitan dengan kejadian-kejadian sekitarnya.

Teknik pengumpulan data dengan observasi dapat digunakan apabila, penelitian berhubungan dengan perilaku manusia, proses kerja, gejala-gejala alam dan bila responden yang diamati tidak terlalu besar.

Kegunaan lain dari observasi lapangan adalah mencocokkan antara hasil wawancara dengan kenyataan yang ada, serta mampu memperoleh data yang tidak dapat diungkapkan melalui wawancara yang hanya dapat diperoleh melalui pengamatan secara langsung terhadap kenyataan di lapangan.

Triangulasi merupakan suatu teknik pemeriksaan data dengan membandingkan data yang diperoleh dari satu sumber ke sumber lainnya dengan pendekatan yang berbeda. Tujuan triangulasi data adalah mengecek kebenaran data tertentu dan membandingkannya dengan data yang diperoleh dari sumber lain.

Penelitian ini menggunakan pedoman wawancara, pedoman observasi serta dokumen-dokumen sebagai instrumennya maka penulis melakukan wawancara serta pencatatan terhadap data dan melakukan observasi terhadap hal-hal yang berkaitan dengan kebijakan program gotong royong di Kecamatan Seberang Ulu 1 di Kota Palembang..Teknik Analisis Data

Teknik analisis data yang diperoleh peneliti dalam pengumpulan data menggunakan teknik analisis kualitatif dengan metode penelitian deskriptif yaitu analisis data yang menggambarkan, melukiskan dan menguraikan data-data yang telah diperoleh berdasarkan keadaan yang sebenarnya di lapangan.

\section{HASIL PENELITIAN DAN PEMBAHASAN}

Pemerintah Kota Palembang berupaya mewujudkan Visi Kota Palembang, yakni
EMAS DARUSSALAM 2023, EMAS yang berarti dan DARUSSALAM yang berarti Kota yang Aman, Damai, Tenteram, Makmur dan Sejahtera serta adanya harmoni antara kehidupan manusia dan alam. Salah satu upaya Pemerintah Kota Palembang mewujudkannya, yakni melalui program gotong royong. Program gotong royong tersebutdilaksanakanmelaluipemberdayaan masyarakat untuk meningkatkan partisipasi masyarakat dalam pelaksanaan program pemerintah, khususnya menimbulkan kesadaran masyarakat dalam menjaga kelestarian lingkungan di Kota Palembang.

Program Gotong Royong ini merupakan program pembersihan saluran air, sungai, dan lingkungan masyarakat dari berbagai macam sampah. Pelaksanaan Program Gotong Royong terbagi menjadi beberapa tingkatan, yakni tingkat kota, kecamatan, dan mandiri/ tingkat rukun tetangga/rukun warga. Gotong Royong dilaksanakan setiap Minggu pagi.

Pada tingkat Kecamatan, sebelum dilaksanakan pada Minggu, masing-masing koordinator menyetorkan tempat atau lokasi pelaksanaan gotong royong di masingmasing kelurahan kepada bagian BKPSDM Wali kota, selanjutnya BKPSDM wali kota akan menentukan tempat atau lokasi yang dilaksanakan gotong royong yang mana diikuti langsung oleh Wali Kota Palembang.

BKPSDM Kota Palembang akan memberitahukan tempat atau lokasi gotong royong yang akan diikuti langsung oleh wali kota kepada camat bersangkutan pada Jumat, sehingga diharapkan camat yang bersangkutan dapat mempersiapkan lokasi, sarana-prasarana terkait pelaksanaan program gotong royong tersebut. Di kecamatan lain yang tidak diikuti langsung oleh wali kota tetap melaksanakan program gotong royong mandiri sesuai jadwal yang telah ditetapkan oleh koordinator program gotong royong di kecamatan.

Pelaksanaan kebijakan program gotong royong yang dilakukan oleh pemerintah 
Kota Palembang merupakan salah satu upaya meningkatkan kesadaran masyarakat terutamanya pada era globalisasi seperti sekarang yang sudah berkurang pemahamannya tentang pentingnya gotong royong.

Program gotong royong yang dicanangkan oleh Wali Kota Palembang ini disosialisasikan kepada masyarakat dengan mengadakan kegiatan safari oleh camat beserta lurah lurah yang ada di Kecamatan Seberang Ulu 1 Kota Palembang. Berdasarkan hasil wawancara dengan Kepala Seksi PMK Kecamatan Seberang Ulu 1, Ria Aryani, pada Senin, 18 Mei 2020 pada pukul 09.00 WIB dilaksanakan di ruang kerjanya, menyatakan bahwa:

"Pelaksanaan program gotong royong disosialisasikan kepada masyarakat Kecamatan Seberang Ulu 1 dengan mengadakan kegiatan safari ke setiap kelurahan yang ada di Kecamatan Seberang Ulu 1 Tujuan diadakannya kegiatan safari ini, yakni untuk membantu dalam kegiatan gotong royong sehingga masyarakat paham dan mengerti akan pentingnya gotong royong dan tergerak untuk turut serta dalam gotong royong. Diharapkan akan timbul mindset dari masyarakat mau untuk membersihkan lingkungan apalagi kita yang tinggal di lingkungan tersebut"

Peraturan Wali Kota Palembang No. 14 Tahun 2019 menimbang bahwa program gotong royong di bidang kebersihan merupakan budaya masyarakat yang perlu terus dilaksanakan secara berkesinambungan, melalui kegiatan gotong royong di bidang kebersihan ini tidak hanya memberikan manfaat dalam menjadikan kawasan permukiman penduduk dan lingkungan menjadi bersih dan indah tapi juga terdapat nilai positif lainnya, yakni silaturahmi, menumbuhkan jiwa keikhlasan dan kerja keras dalam bekerja.
“Kelengkapan sarana dan prasarana penyelenggaraan program gotong royong di Kecamatan Seberang Ulu 1 Kota Palembang sangat memenuhi dalam sarana dan prasarana dan hal itulah yang membuat masyarakat mengenal kecamatan itu sebagai kecamatan yang bersih".

Kegiatan gotong royong kebersihan lingkungan ini memberikan perubahan dalam kehidupan masyarakat ke arah yang lebih baik, yakni sebagaimana yang disampaikan oleh Lurah 3-4 Ulu, Misrinah, pada Selasa, 19 Mei 2020 pada pukul 10.00 WIB dilaksanakan di ruang kerjanya, menyatakan bahwa:

"Program gotong royong ini meningkatkan disiplin dan rasa sadar warga dalam kebersihan lingkungan sekitar. Hal ini terlihat dari lingkungan yang bersih dan indah. Masyarakat juga sudah mulai memilah sampah seperti sampah organik dan non-organik, dan hal tersebut juga menciptakan rasa toleransi dan peduli terhadap sesama masyarakat".

Dari hasil wawancara di atas dapat disimpulkan bahwa program gotong royong merupakan kebijakan Pemerintah Kota Palembang yang diatur dalam Peraturan Wali Kota Palembang No. 14 Tahun 2019 tentang Pelaksanaan Gotong Royong Tingkat Kota, Gotong Royong Tingkat Kecamatan, dan Gotong Royong Mandiri Tingkat RT/RW yang memberikan begitu banyak manfaat di antaranya adalah meningkatkan kesadaran/ partisipasi masyarakat dalam menjaga kebersihan lingkungan.

Pelaksanaan Gotong Royong telah berjalan sejak tahun 2015, yang menjadi latar belakang terbentuknya kebijakan ini adalah sebagai upaya dari pemerintah dalam melestarikan budaya gotong royong dan untuk mewujudkan Visi Kota Palembang, yakni Palembang EMAS Darussalam 2023 melalui pemberdayaan masyarakat dan 
peningkatan partisipasi masyarakat dalam menjaga kelestarian lingkungan di Kota Palembang khususnya Kecamatan Seberang Ulu 1 Palembang.

\section{Kecamatan Seberang Ulu 1 Palembang}

Secara fisik, sarana prasarana yang disediakan oleh kecamatan menjadi indikator menilai pelaksanaan kebijakan program gotong royong. Sarana yang dimaksud mencakup penyediaan peralatan kebersihan yang akan dipakai dalam kegiatan gotong royong, sedangkan prasarana yang dimaksud adalah TPS dan kendaraan operasional dari pemerintah Kota Palembang sehingga dapat dilaksanakannya kegiatan gotong royong sesuai dengan jadwal yang sudah ditentukan.

Sarana yang diperlukan untuk kegiatan gotong-royong membersihkan lingkungan antara lain: sapu lidi, sekop, cangkul, gerobak sampah, kantung sampah, mesin gunting rumput, dan lain-lain. Pihak kecamatan menyediakan sebagian peralatan tersebut yang digunakan untuk kebersihan pada minggu-minggu tertentu. Apabila dalam satu kali pembersihan alat-alat tersebut hilang/ rusak, maka pada pembersihan selanjutnya akan dikembalikan lagi kepada masyarakat untuk disediakan secara swasembada. Hal ini didukung dari pernyataan Plh. Kepala Seksi Pelayanan Umum Kecamatan Seberang Ulu 1, Elwien Zein, pada Senin, 18 Mei 2020 pukul 11.00 WIB yang mengurusi soal alatalat kebersihan sebagai berikut.

"Kami dari pihak Kecamatan sudah menyiapkan alat-alat kebersihan seperti sapu lidi, sekop, cangkul, gerobak sampah, kantung sampah, mesin gunting rumput, dll. Dan kami telah menyerahkan tanggung jawab secara penuh kepada masyarakat untuk bertanggung jawab terhadap alat-alat kebersihan tersebut maka dari itu jika dari alat-alat itu ada yang rusak atau hilang masyarakatlah yang harus menyediakan kembali alat- alat tersebut untuk kegiatan gotong royong selanjutnya".

Menariknya dari kegiatan pembersihan tersebut adalah kaum yang langsung menyiapkan makanan dan minuman, dan beberapa di antaranya ada yang ikut membantu menyapu serta mengumpulkan sampah-sampah di sekitar tempat tinggal. Anak-anak yang masih kecil dibiarkan bermain di dalam rumah, sedangkan yang beranjak remaja diarahkan untuk membantu kaum dalam mengumpulkan semua sampah. Kegiatan pembersihan dimulai sejak pukul 06.00 hingga pukul 09.00 pagi.

Keterangan tersebut didapatkan dari Camat Seberang Ulu 1, Jufriansyah, pada Rabu, 20 Mei 2020 pukul 09.00 di ruang kerjanya yang menyatakan bahwa:

"Iya, saya sempat dipanggil oleh wali kota melalui dinas terkait untuk menyampaikan kondisi terkini di lapangan. Pada forum rapat tersebut, saya utarakan kepada pimpinan jika masyarakat di wilayah saya khususnya, masih menyimpan nilai-nilai budaya lama. Nilai-nilai yang saya maksudkan di situ ada nilai kebersamaan, nilai gotong royong, dan sebagainya. Tapi saya juga tidak munafik kalau golongan muda justru meninggalkan kesan unsur individualis dan acuh tak acuh, terutama terhadap lingkungan. Selama ini, orangorang tua yang banyak mengisi kegiatan kemasyarakatan, sedangkan yang muda vakum. Masih saya coba untuk dalami apa yang menjadi penyebabnya".

Pernyataan tersebut menunjukkan bahwa adanya input yang datang dari bawah atau SKPD struktural pemerintah daerah. Usulan camat pun direspons oleh pemerintah daerah dengan mengesahkan Perwali tersebut. Peneliti belum mampu menganalisis proses pembuatan kebijakan peraturan wali kota yang dimaksud karena sudah melewati rentan waktu pada tahapan formulasi kebijakan. Oleh karena itu, peneliti 
lebih memperhatikan ketegasan dalam pelaksanaan dan penerapan kebijakan yang diturunkan ke kecamatan untuk diteruskan kepada masyarakat.

\section{Target Group}

Target Group yang dibahas dalam penelitian ini merupakan masyarakat. Hasan Shadily mengatakan masyarakat adalah golongan masyarakat yang secara sendirinya mengikat satu dengan yang lain dalam pengaruh maupun memengaruhi. Sedangkan menurut Djojodiguno, masyarakat merupakan kesatuan kehidupan antar manusia. Pendapat yang juga mengatakan masyarakat adalah suatu kelompok dari manusia yang memiliki tatanan kehidupan, norma-norma adat istiadat yang sama-sama menyepakati dalam kehidupan mereka.

Dapat disimpulkan masyarakat dalam penelitian ini adalah sekelompok orang yang memiliki tatanan kehidupan, norma serta adat istiadat yang telah disepakati secara bersama-sama. Kelompok masyarakat yang dimaksud dalam penelitian ini adalah masyarakat yang bertempat tinggal di daerah Kecamatan Seberang Ulu 1 Kota Palembang Provinsi Sumatra Selatan.

\subsection{Sub Dimensi Kelompok}

Implementasi program gotong royong ini menyasar masyarakat secara umum, seluruh warga yang menduduki wilayah Kota Palembang wajib melaksanakan peraturan tersebut. Indikator yang dimasukkan dalam sub dimensi kelompok mencakup kelompokkelompok masyarakat yang terbagi dalam kecamatan, kelurahan. Bahkan sampai tingkat RW dan RT. Setiap RT harus dapat melaksanakan program gotong royong lingkungan dengan berlandaskan peraturan wali kota yang sudah ditetapkan.

Untuk penelitian ini, pengamatan dilakukan pada salah satu kecamatan, yaitu Kecamatan Seberang Ulu 1. Secara garis besar, kegiatan gotong royong sudah dilaksanakan namun belum merata di beberapa lokasi
RT maupun RW yang berada di wilayah kecamatan. Hal tersebut disampaikan oleh Camat Seberang Ulu 1 Jufriansyah yang menyatakan bahwa:

"Program gotong royong ini sudah terlaksana di sebagian besar wilayah Kecamatan Seberang Ulu 1, namun pada beberapa wilayah RT maupun RW belum dapat terlaksana dikarenakan beberapa hambatan yaitu sarana dan prasarana yang belum memadai dikarenakan beberapa alat-alat kebersihan yang rusak dan hilang tetapi belum disediakan oleh masyarakat secara swasembada“.

\subsection{Sub Dimensi Individu}

Sasaran implementasi program gotong royong secara individu dinilai dari indikator perorangan. Artinya, setiap jiwa memahami pentingnya gotong royong serta kesadaran terhadap kebersihan lingkungan. Peneliti mengambil sampel acak untuk dapatkan jawaban pemahaman warga soal peraturan wali kota, yakni tokoh masyarakat dan salah seorang kepala keluarga berusia 30an atas nama Budi Winarno. Berdasarkan keterangan Pak Budi dalam wawancaranya:

«Saya belum mengerti banyak soal isi Perwali itu, pak. Jujur saja, saya juga baru bekerja secara gotong royong ini dari ketua RT setempat. Ya, karena saya orang pindahan saya ikuti saja arahan beliau, sekaligus saya berinteraksi dengan tetangga-tetangga. Kalau untuk pengumuman langsung dari pemerintah daerah, saya belum pernah dengar secara langsung. Atau karena saya hanya lihat media sosial ya, jadinya berita yang dekat malah tidak tahu».

Keterangan yang berbeda didapatkan dari tokoh masyarakat di RW 05 yang bernama Pak Bambang selaku pengurus keagamaan kegiatan masyarakat.

«Karena saya sudah cukup lama di lingkungan ini, kurang lebih 30 tahun, kadang ada aparat kecamatan yang 
tanya-tanya ke saya atau sekadar ngobrol santai begitu. Perwali yang maksud itu saya pernah disampaikan sama pegawai kecamatan kalau mau dimulai dari awal tahun 2019 lalu. Ya, saya teruskan saja ke tetangga-tetangga, yang datang ke masjid dan yang ketemu di jalan“.

\section{Program}

Dalam penelitian ini program yang dimaksud adalah program Gotong Royong di lingkungan pemerintahan Kecamatan Seberang Ulu 1 Kota Palembang Provinsi Sumatra Selatan. Kegiatan yang termasuk dalam unsur implementasi kebijakan mencakup kegiatan oleh masyarakat berupa pelaksanaan kerja bakti selama observasi oleh peneliti, dan kegiatan sosialisasi yang menjadi kewajiban aparatur kecamatan dalam rangka menerapkan peraturan Wali kota.

Berdasarkan penelitian yang dilakukan, tanpa terpaut dengan teori Syukur, peneliti menilai proses dari implementasi kebijakan program gotong royong terhadap sosialisasi program ini kepada masyarakat di Kecamatan Seberang Ulu 1 Kota Palembang, sebagaimana menurut Soerjono Soekanto kebudayaan kepada warga masyarakat yang baru. Secara umum, sosialisasi didefinisikan sebagai proses penanaman atau transfer kebiasaan atau nilai dan aturan dari satu generasi ke generasi lainnya dalam sebuah kelompok atau masyarakat. Sejumlah menyebut sosialisasi sebagai teori mengenai peranan. Karena dalam proses sosialisasi diajarkan peran-peran yang harus dijalankan oleh individu..

Dalam wawancara yang dilakukan peneliti dengan Kasi Bidang Pemberdayaan Masyarakat Kota, Ria Aryani, di ruang kerjanya, menyatakan bahwa:

"Kesadaran masyarakat untuk pelaksanaan gotong royong memang masih kurang, masih ada masyarakat yang hanya melihat-lihat saja ketika gotong royong berlangsung, namun ada per` ubahan yang terjadi pada sikap masyarakat setelah dilaksanakan sosialisasi dan kegiatan gotong royong di lingkungan tersebut, masyarakat lebih menjaga kebersihan lingkungan, yakni tidak membuang sampah sembarangan seperti sebelumnya di lokasi pelaksanaan gotong royong tersebut".

Hal serupa peneliti dapat dari wawancara dengan lurah Kelurahan 3-4 Ulu Misrinah, pada Selasa, 19 Mei 2020, pukul 10.00 WIB yang menyatakan bahwa masih kurangnya partisipasi masyarakat saat pelaksanaan gotong royong namun terdapat perubahan dari masyarakat, yakni meningkatnya kepekaan masyarakat untuk menjaga kebersihan seperti tidak membuang sampah sembarangan.

Data tersebut sesuai dengan pengamatan peneliti, yakni masyarakat yang ikut berpartisipasi pada saat gotong royong berlangsung memang masih minim namun peneliti mengamati selama dua minggu setelah pelaksanaan gotong royong di Jalan K.H. Wahid Hasyim Kelurahan 1 Ulu, lokasi tersebut masih terlihat bersih dan tidak ada yang membuang sampah sembarangan seperti sebelum dilaksanakannya sosialisasi kegiatan gotong royong kepada masyarakat.

Meskipun perubahan pada masyarakat belum optimal namun, kebijakan gotong royong telah memberikan dampak positif yaitu menumbuhkan kepekaan dan perubahan dalam diri masyarakat dengan terciptanya masyarakat yang sukarela menjaga kebersihan lingkungan yang tidak membuang sampah sembarangan. Hal tersebutlah yang diharapkan Pemerintah Kota Palembang dari diselenggarakannya kebijakan ini, yakni minimal meningkatkan kesadaran/kepekaan masyarakat untuk menjaga kebersihan lingkungan. Oleh karena itu, pelaksanaan program gotong royong perlu untuk terus ditingkatkan dari berbagai aspek terutama dalam sosialisasi 
kepada masyarakat sehingga tujuan dari kebijakan ini, yaitu meningkatkan semangat gotong royong masyarakat dalam menjaga kebersihan lingkungan dapat tercapai dengan optimal.

Berdasarkan wawancara dengan Kepala Seksi Bidang PMK Kecamatan Seberang Ulu 1 Ria Aryani, pada Rabu, 20 Mei 2020 pada pukul 09.00.

"Program gotong royong memang lebih gencar dilakukan lewat media sosial, namun tentunya hal ini memiliki kekurangan, yakni khususnya masyarakat yang sudah berumur cenderung lebih sulit untuk aktif di media sosial seperti keterangan dari lurah 5 Ulu, Istighfar Cholik S."

Sejalan dengan keterangan di atas, ketua RT 60 Kelurahan 5 Ulu, Jazuli Husin, pada saat wawancara Rabu, 20 Mei 2020 pukul 09:00 WIB di kediaman beliau, menyatakan bahwa:

"Kami jarang mendapatkan sosialisasi terkait program gotong royong. Saya sendiri cuma mendapatkan informasi gotong-royong pada saat awal awal adanya program ini, selain itu tidak ada pemberitahuan selanjutnya“.

\section{Unsur Pelaksanaan}

Berdasarkan wawancara dengan Kepala Seksi Bidang PMK Kecamatan Seberang Ulu 1, Ria Aryani, pada Senin, 6 Januari 2020 pada pukul 09.00:

"Kalau untuk sosialisasi memang saya rasa kurang karena pertemuan khusus terkait program ini hanya diadakan pada masa awal-awal program dijalankan, selebihnya hanya pemberitahuan kepada RT setempat dan biasanya pemberitahuan ini hanya lewat sosial media“.

Sejalan dengan keterangan di atas, ketua RT. 60 Kelurahan 5 Ulu, Jazuli Husin, pada saat wawancara, Senin, 18 Mei 2020 pukul
09:00 WIB di kediaman beliau, menyatakan bahwa:

"Kami jarang mendapatkan sosialisasi terkait program gotong royong.

Pelaksana kebijakan yang dikeluarkan oleh Wali Kota Palembang dari segi organisasi pada penelitian ini adalah kecamatan secara keseluruhan. Organisasi Kecamatan Seberang Ulu 1 sebagian masih diisi oleh pelaksana tugas dan mempekerjakan pegawai tidak tetap dengan kapasitas kerja yang menuntut keterlibatan semua anggota. Kondisi tersebut sudah dimaksimalkan oleh kecamatan supaya semua tetap terlibat dan turun langsung dalam kegiatan pembersihan dan gotong royong di lokasi-lokasi yang sudah dibagi. Hal ini sesuai dengan keterangan dari Kepala Seksi Pemerintahan, Aris Varizal, yang menyatakan bahwa:

"Pihakkecamatansudahmenindaklanjuti Peraturan Wali Kota Palembang No. 14 Tahun 2019 tentang Pelaksanaan Gotong Royong dengan memberikan sosialisasi kepada setiap kelurahan. Ketika Perwali itu pertama disahkan, kecamatan langsung memanggil setiap lurah dan menyebarluaskan arahan pimpinan terkait kegiatan ini. Kemudian, tinggal di masing-masing kelurahan mengumpulkan setiap RW untuk mulai dilaksanakan dari waktu yang sudah kita tetapkan. Nah, ini yang belum kami tinjau, apakah di semua kelurahan sudah memberikan informasi secara tepat atau tidak, karena pelaksanaannya selama ini tersendat".

Organisasi yang berdiri bergerak sesuai dengan petunjuk pimpinan. Dalam konteks ini, organisasi kecamatan dipimpin oleh seorang camat yang mengepalai anggotaanggotanya sejumlah 3 orang ditambah dengan lurah yang bertugas di wilayah masing-masing. Camat Seberang Ulu 1 menindaklanjuti peraturan wali kota tentang 
pelaksanaan gotong royong dengan terlibat langsung dalam kegiatan yang dilaksanakan setiap minggunya.

Selain itu, Jufriansyah, selaku Camat Seberang Ulu 1 juga memerintahkan anggotanya untuk melakukan sosialisasi kepada lurah dan RW yang ada di wilayahnya. Beliau juga meninjau langsung kegiatan pembersihan gotong royong di RW 05 misalnya, yang menjadi lokasi pengamatan peneliti. Camat hadir lima belas menit atau sekitar pukul 05.45 WIB, tepatnya sebelum masyarakat memulai kegiatan gotong royong. Setelah itu, beliau berada di tempat sampai dengan pukul 07.00 WIB karena harus mengecek lokasi lainnya.

Hasil wawancara dengan Pak Budi selaku tokoh masyarakat, camat memang rajin hadir di kegiatan yang berkaitan dengan pemerintah daerah. Selain kegiatan gotong royong, camat juga sering datang pada kegiatan sosialisasi dari pemerintah daerah. Tidak terlepas dari jabatannya, camat terkadang hadir dalam kegiatan warga sehingga masyarakat banyak menghargai peran beliau. Berikut hasil wawancara peneliti dengan tokoh masyarakat:

"Pak camat sering datang ke daerah sini, kadang buat main saja tapi lebih sering kalau ada perintah atau kegiatan dari pemerintah daerah. Kalau sedang ada kegiatan warga kemudian beliau datang, ya kadang beliau memberikan sambutan atau sekadar menyapa warga. Gotong royong yang dibuat sama wali kota juga saya sering lihat beliau ikut meskipun tidak lama. Ya, kami mengerti karena beliau juga sibuk atau mungkin ada urusan lain. Dengan begitu saja, kami menjadi lebih akrab dan lebih mengenal beliau".

\section{Faktor Pendukung Implementasi Kebijakan Program Gotong Royong}

Pelaksanaan suatu kebijakan yang terbentuk dalam suatu program tidak akan optimal pencapaiannya apabila tidak ada faktor pendukung dalam pelaksanaan program tersebut. Dalam program gotong royong yang telah ditetapkan oleh pemerintah Kota Palembang yang tertuang pada Peraturan Wali Kota Palembang No. 14 Tahun 2019 tentang pelaksanaan program gotong royong juga memerlukan faktor pendukung agar program ini dapat mencapai hasil yang optimal..

Faktor pendukung berupa dukungan materi berupa sarana dan prasarana dari pemerintah Kota Palembang melalui pengadaan yang dana nya berasal dari anggaran APBD. Seperti hasil wawancara dengan Kepala Dinas Lingkungan Hidup dan Kebersihan Kota Palembang, Alex Fernandus pada Kamis, 24 Mei 2020 Pukul 14.00 WIB s.d. selesai, di ruang kerjanya, mengatakan bahwa:

"Selain memberikan dukungan secara non-materi. Pemerintah Kota Palembang juga memberikan dukungan secara materi dengan menganggarkan dana pelaksanaan program gotong royong melalui APBD Kota Palembang untuk pengadaan sarana prasarana penunjang program gotong royong ini sebesar Rp5.000.000,00 dipotong pajak PPH 10\% jadi Rp4.500.000,00 per bulan yang diberikan kepada setiap kelurahan untuk menunjang kegiatan gotong royong, yakni berupa penyediaan makan dan minum bagi seluruh pelaksana setelah pelaksanaan kegiatan“.

Kemudian faktor pendukung lainnya, yakni adanya dukungan dari unsur aparat pemerintahan yaitu lurah, u RW dan RT yang ada di Kecamatan Seberang Ulu 1 Kota Palembang dalam pelaksanaan program gotong royong ini dengan melakukan sosialisasi tentang program gotong royong dan terjun langsung dalam kegiatan gotong royong tersebut. Hal tersebut dilakukan agar dapat lebih memberikan semangat dan mampu menjadi motivator kepada masyarakat untuk menjaga kebersihan bersama. 
Faktor Penghambat dalam Implementasi Kebijakan Program Gotong Royong

Adapun beberapa faktor penghambatan yang terjadi dalam pelaksanaan program gotong royong di Kecamatan Seberang Ulu 1 Kota Palembang antara lain sebagai berikut.

\section{- Kurangnya kedisiplinan aparat pemerintah}

Kedisiplinan aparat pemerintah dalam pelaksanaan program gotong royong dinilai masih kurang. Walaupun respons dari aparat pemerintah mendukung adanya program gotong royong namun, apabila tidak dilaksanakan dengan disiplin tentunya akan menghambat pelaksanaan gotong royong. Seperti data yang didapatkan dari wawancara dengan. Faizhal AR, selaku Asisten I bagian Pemerintahan dan Kesejahteraan Rakyat Kota Palembang pada Rabu, 22 Januari 2020 Pukul 13:00 WIB s.d. selesai di ruang kerjanya menyatakan bahwa:

"Pada umumnya pegawai pemerintah Kota Palembang telah melaksanakan program gotong royong secara disiplin sesuai ketentuan yang berlaku, namun memang ada beberapa pegawai yang belum disiplin dalam hal ini, seperti tidak hadir tanpa keterangan saat pelaksanaan gotong royong"

\section{- Kurangnya pemahaman masya- rakat tentang program gotong royong}

Kesadaran masyarakat untuk ikut berpartisipasimelaksanakan programgotong royong masih kurang. Pemahaman tentang program ini dan kemauan masyarakat dalam mengikuti program gotong royong memang sangat dibutuhkan untuk menumbuhkan kebersamaan antar masyarakat itu sendiri dan juga antara masyarakat dengan pemerintah dalam menjaga kebersihan lingkungan Kota Palembang, khususnya di Kecamatan Seberang Ulu 1 Kota Palembang.
Pelaksanaan gotong royong telah banyak menimbulkan dampak positif salah satunya, yakni meningkatnya partisipasi masyarakat dalam menjaga kebersihan lingkungan. Namun juga masih dirasakan banyak masyarakat yang enggan untuk ikut berpartisipasi langsung dalam pelaksanaan program gotong royong ini. Sebagaimana wawancara dengan Plt. Camat Seberang Ulu 1 Palembang, Jufriansyah, pada Senin, 6 Januari 2020 pukul 14:00 WIB, di ruang kerjanya, yang menyatakan bahwa:

"Dalam hal menjaga kebersihan lingkungan sebenarnya sudah dirasakan adanya perubahan yang lebih baik dari masyarakat untuk menjaga kebersihan lingkungan minimal di lingkungan mereka masing-masing, namun khusus untuk pelaksanaan program gotong royong ini masih dirasakan kurangnya partisipasi masyarakat untuk ikut langsung dalam pelaksanaan gotong royong ini, mereka lebih banyak hanya melihat saja dan sibuk dengan aktivitas mereka masing masing“.

\section{- Sarana dan prasarana yang belum memadai}

Sarana dan Prasarana yang belum memadai dalam penunjang kebersihan merupakan faktor penghambat dalam implementasi kebijakan. Pada pelaksanaan program gotong royong diperlukan adanya sarana dan prasarana penunjang kebersihan lingkungan, sehingga hasil dari program gotong royong yang telah dilaksanakan tersebut dapat terus terjaga. Di Kota Palembang, sarana dan prasarana penunjang kebersihan masih belum memadai. Hal tersebut berdasarkan hasil wawancara dengan Kepala Dinas Lingkungan Hidup, Alex Fernandus, pada Kamis, 24 Mei 2020 pukul 14:00 WIB di ruang kerjanya, mengatakan bahwa:

“Terkait sarana dan prasarana penunjang kebersihan lingkungan memang saat ini 
belum optimal atau belum memadai berdasarkan rasio luas wilayah Kota Palembang.

Kemudian Khusus Kecamatan Seberang Ulu 1 sarana dan prasarana yang belum memadai terutama TPS. Hal ini berdasarkan Wawancara dengan Plt. Camat Seberang Ulu 1 Palembang, Jufriansyah, pada Senin, 18 Mei 2020 pukul 14:00 WIB, di ruang kerjanya, menyatakan bahwa:

"Untuk Kecamatan Seberang Ulu 1 ini sarana dan prasarana fasilitas penunjang kebersihan lingkungan yang masih belum memadai yaitu TPS-nya“.

Dari wawancara yang telah dilaksanakan bahwa faktor penghambat pelaksanaan program gotong royong selain kurangnya disiplin aparat pemerintah dan masih kurangnya partisipasi masyarakat yaitu kurang memadai sarana dan prasarana penunjang kebersihan di Kecamatan Seberang Ulu 1 Palembang.

\section{Solusi Menyelesaikan Faktor Penghambat Dalam Implementasi Kebijakan Program Gotong Royong Di Kecamatan Seberang Ulu 1 Kota Palembang}

Menyikapi fenomena tersebut, hal yang harus kita lakukan adalah memikirkan cara agar kubu pro tetap konsisten bepihak pada program yang ingin kita wujudkan. Serta memikirkan cara yang ampuh agar kubu kontra menyadari pentingnya dari kebijakan ini sehingga dapat mendukung semua program yang ingin kita wujudkan serta kita capai.

Berikut langkah-langkah yang dapat kita ambil agar masyarakat menjadi terarah dalam satu kubu untuk mendukung program pengembangan Peraturan Wali Kota Palembang No. 14 Tahun 2019 terhadap partisipasi masyarakat di Kecamatan Seberang Ulu 1 tentang Pelaksanaan Gotong Royong :.
Sosialisasi yang dimaksud dalam bentuk himbauan melalui media cetak, elektronik maupun penyampaian secara langsung melalui suatu perkumpulan. Salah satu keuntungan dari sosialisasi melalui media elektronik yaitu mudah di akses dan dijangkau oleh masyarakat luas, yang mana himbauan tentang gotong royong ini akan dengan mudah tersebar. Contohnya yaitu membuat website, akun Instagram dan akun media sosial lainnya karena aksesnya yang sangat mudah dijangkau oleh masyarakat.

Peraturan Wali Kota Palembang No. 14 Tahun 2019 belum menjelaskan sama sekali terkait teknis sosialisasi di media sosial. Dari sini, penulis memberikan masukan kepada pemerintah daerah untuk menjelaskan lebih rinci terkait tugas-tugas SKPD yang berada di bawah Dinas Lingkungan Hidup dan Kebersihan dan Badan Kepegawaian dan Sumber Daya Manusia. Peraturan Wali Kota Palembang dapat diturunkan ke dalam surat edaran maupun pengumuman resmi yang disebarkan ke seluruh lokasi pembersihan di kecamatan yang ada di Kota Palembang.

Pemerintah Daerah Kota Palembang seharusnya dapat memasukkan media sosial resmi seiring dengan disahkannya peraturan wali kota tersebut. Dengan adanya media sosial resmi dari pemerintah daerah, masyarakat juga akan semakin mudah mengakses informasi terbaru dan kebutuhan yang diperlukan untuk menyukseskan kebijakan yang dibuat. Media sosial pemerintah daerah juga sebaiknya segera mendekat kepada seluruh lapisan masyarakat agar mendapatkan respons balik yang cepat sebagai bahan evaluasi pemerintah Kota Palembang.

Sosialisasi tentang gotong royong harus menganut 5 nilai dasar, yaitu kebersamaan, persaudaran, rela berkorban, tolong menolong dan sosialisasi, di mana Gotong royong dapat membuat manusia kembali sadar jika dirinya adalah makhluk sosial. Gotong royong membuat masyarakat 
saling mengenal satu sama lain sehingga proses sosialisasi dapat terus terjaga keberlangsungannya..

\section{- Pemberian fasilitas}

Pemerintah Kota Palembang dapat menjelaskan lagi terkait fasilitas yang akan diberikan kepada masyarakat. Fasilitas yang dimaksud bisa lebih dijelaskan dalam bentuk yang lebih konkret. Artinya, di dalam pasal tersebut dapat disebutkan fasilitas apa saja yang akan didukung pemerintah daerah sehingga masyarakat lebih paham tentang program yang akan diselenggarakan di tengah-tengah masyarakat.

Aparat pemerintahan baik kecamatan maupun kelurahan dalam penyelenggaraan kegiatan gotong royong juga menyediakan terkait dana yang bersifat stimulus bagi masyarakat setempat dengan maksud agar masyarakat mau menyumbang sebagian penghasilannya. Masyarakat dihimbau memberikan fasilitas alat dan kebutuhan untuk menunjang optimalnya kegiatan yang akan dikerjakan, dan disediakannya hidangan/makanan ringan dan minuman pada saat kegiatan berlangsung agar minat dan partisipasi masyarakat dalam kegiatan gotong royong meningkat..

\section{Penjelasan Pasal Sanksi dan Apresiasi}

Peraturan wali kota yang mencakup seluruh komponen termasuk PNS, pegawai BUMD, hingga berbagai lapisan masyarakat seharusnya dapat lebih lengkap dalam isi peraturan dan menggerakkan masyarakat sekaligus. Dari isi peraturan wali kota, pegawai yang tidak datang pada kegiatan gotong royong hanya diberikan sanksi administrasi. Apabila ingin bertindak tegas, pemerintah kota dapat menjatuhkan sanksi lebih kepada pegawai, misalnya dengan surat teguran hingga pemotongan honor/ tunjangan.

Selain itu, belum ada sanksi yang mengikat kepada masyarakat yang disebutkan dalam pasal. Ini menunjukkan bahwa pemerintah kota belum serius untuk memaksimalkan kegiatan gotong royong di daerah atau lokasi yang telah ditentukan. Sebagai masukan, pemerintah kota dapat menjelaskan di dalam peraturan wali kota tersebut atau turunannya tentang sanksi yang akan didapatkan anggota masyarakat apabila tidak melaksanakan gotong royong di wilayahnya. Contohnya, diberikan sanksi bayar denda per jiwa dalam satu keluarga, atau sanksi lain yang dapat memberikan kesadaran bagi pemerintah daerah maupun masyarakatnya sendiri.

Bila masyarakat sudah ditindak dengan sanksi jika melanggar, maka perlu menjaga keseimbangan dengan pemberian apresiasi atau penghargaan. Selain bentuk penyeimbangan, masyarakat juga akan terdorong dan lebih sadar untuk bergotong royong dengan diapresiasi atau penghargaan dari pemerintah daerah. Adanya penghargaan dan apresiasi terhadap kegiatan gotong royong yang dilaksanakan, contohnya yaitu dengan mengadakan lomba kebersihan yang nantinya, pemenangnya akan mendapatkan reward khusus, dan untuk semua masyarakat yang ikut berpartisipasi pun tetap mendapatkan reward berupa diadakannya suatu hiburan rakyat.

\section{SIMPULAN}

Kebijakan program Gotong Royong di Kecamatan Seberang Ulu 1 Kota Palembang dapat digolongkan sudah baik dan terlaksana sesuai tujuan, yang dijelaskan berdasarkan teori Syukur 1988 dan indikator-indikator yang telah ditentukan sebelumnya.

Faktor pendukung pada pelaksanaan program ini terletak pada dukungan dana dari pemerintah daerah, materi teknis dari kecamatan, dan sosialisasi serta partisipasi pada pelaksana program.

Adapun faktor penghambat pada pelaksanaan program ini terletak pada sarana prasarana yang masih belum 
memadai dari faktor Pengembangan Peraturan Wali kota No. 14 Tahun 2019 tentang Pelaksanaan Gotong Royong Tingkat Kota, Kecamatan, RT/RW dapat ditambahkan dengan mengadakan sosialisasi, pemberian fasilitas, dan penjelasan pada pasal sanksi dan apresiasi.

Penelitian Program Gotong Royong selanjutnya diharapkan dapat mengambil permasalahan yang lain serta sudut pandang yang berbeda sehingga dapat memperluas ilmu dan khasanah penelitian selanjutnya. Juga sangat penting lebih mmperjelas pasal dan aturan yang tercantum dalam Peraturan Wali kota terkait sanksi dan apresiasi.

\section{DAFTAR RUJUKAN}

Abdullah, Syukur, 1988. Perkembangan Studi Implementasi. Lembaga Administrasi Negara Republik Indonesia. Jakarta.

Abidin, Said Zainal, 2004. Kebijakan Publik. Jakarta: Yayasan Pancur Siwah.

Agustino, Leo. 2008. Dasar-dasar Kebijakan. Bandung: Alfabeta

Anderson, J. E, Brady, D. W, Bullock, C. S, \& Stewart, J. 1978. Public policy and politics in America (p. ix). North Scituate, MA: Duxbury Press.

Arikunto, S. (2013). Prosedur Penelitian: Suatu Pendekatan Praktik. Jakarta: Rineka Cipta.

Azwar, Saifuddin. 2011. Metode Penelitian. Yogyakarta: Pustaka Pelajar.

Bintarto. 1980. Gotong Royong Suatu Karakteristik Bangsa Indonesia. Yogyakarta. Bina Ilmu Surabaya

Bungin, B, 2017. Penelitian Kualitatif: komunikasi, ekonomi, kebijakan publik, dan ilmu sosial lainnya. Kencana.

Dye, Thomas R. 1992. Understanding Public Policy. USA: Prentice-Hall, INC., Englewood Cliffs, NJ.

Friedrich, C. J. 1940. Public policy and the nature of administrative responsibility. Public, 3-24.
Eyestone, R. 1971. The threads of public policy: A study in policy leadership. Ardent Media.

Gaventa, J, \& Valderrama, C. (1999, June). Participation, citizenship and local governance. In Background note for the workshop "Strengthening Participation in Local Governance, "University of Sussex, Institute of Development Studies (Vol. 21).

Gunawan, Imam. Metode Penelitian Kualitatif.: Teori dan Praktik Jakarta: Bumi Aksara. 2013.

Jones, Charles O. 1996. Pengantar Kebijakan Publik (Public Policy). Terjemahan Ricky Ismanto. Jakarta: Raja Grafindo Persada.

Kamus Besar Bahasa Indonesia. 2002

Kartodirdjo, S. (1987). Pengantar sejarah Indonesia baru, 1500-1900: Dari emporium sampai imperium (Vol. 1). Gramedia.

Koenjtaraningrat. 1974. Kebudayaan Mentalitas dan Pembangunan. Jakarta: Gramedia Pustaka Utama.

1985. Kebudayaan, Mentalitas, dan Pembangunan. Jakarta: Gramedia

Lasswell, H. D, \& Kaplan, A. 2013. Power and society: A framework for political inquiry. Transaction Publishers.

Marzali, Amri. 2005. Antropologi pembangunan Indonesia. Jakarta: Kencana

Matsui, Y. 2001. Lingkungan Hidup. Jakarta:JICA

Moleong, Lexy. J. 2016. Metodologi Penelitian Kualitatif Edisi Revisi. Bandung: Remaja Rosdakarya.

Nazir, Moh. 2011. Metode Penelitian. Bogor: Ghalia Indonesia.

Noor, Juliansyah. 2014. Metodologi Penelitian. Kencana. Jakarta.

Nugroho D, Rianto. 2012. Public Policy. Jakarta: Gramedia

Purwanto, E. A. 2012. Implementasi Kebijakan Publik Konsep dan Aplikasinya di Indonesia (No. 1). 2012.

Sajogyo dan Pudjiwati. 2005. Sosiologi Pedesaan. Yogyakarta: Gadjah Mada University Press. 
Sugiyono. 2009. Metode Penelitian Kuantitatif Kualitatif dan R\&D. Bandung: Bumi Aksara

2017. Memahami Penelitian Kualitatif. Bandung: Alfabeta

Winarno, Budi. 2012. Kebijakan Publik Teori. Yogyakarta: Gajah Mada Press

\section{Jurnal \& Makalah}

Abdillah, B. (2011). Gotong Royong Cermin Budaya Bangsa Dalam Arus Globalisasi. Dalam makalah Seminar.

Astuti, D, \& Irene, S. (2009). Desentralisasi dan Partisipasi dalam pendidikan. Yogyakarta: UNY.

Buhungo, R. A. (2012). Faktor Perilaku Kesehatan Masyarakat dan Kondisi Lingkungan Rumah Dengan Kejadian Malaria. Jurnal Health and Sport, 5(2).

Edward III, G. C. (1978). Understanding Public Policy. New Jersey: Prantice Hall.

(1980). Implementing Public Policy. Washington: Congressional Quarterly.

Pasha, Ahmad. 2009. Kebudayaan Indonesia. Jakarta: Erlangga

Pasya, G. K. (2000). Gotong royong dalam kehidupan masyarakat. SOSIETAS, 1(1).

Stewart Jr, J, Hedge, D. M, \& Lester, J. P. (2007). Public policy: An evolutionary approach. Nelson Education.

Ripley, R. B, \& Franklin, G. A. (1986). Policy implementation and bureaucracy. Brooks/Cole.

Van Meter, D. S, \& Van Horn, C. E. (1975). The policy implementation process: A conceptual framework. Administration \& Society, 6(4), 445-488.

\section{Rujukan Elektronik}

Lastriyah. 2011. Kebersihan Lingkungan. http:// lastriyah-identitas.blogspot.com/diakses 09 Januari 2020

Prof. Dr. M. Abdurrahman, MA. 2013. Kebersihan dan Kesehatan Lingkungan Dalam Islam https://minanews.net/kebersihan-dankesehatan-lingkungan-dalam-islam/ diakses 09 Januari 2020

\section{Peraturan Perundang-Undangan}

Undang-Undang No. 23 tahun 1997 tentang Pengelolaan Lingkungan Hidup

Undang-Undang No. 23 Tahun 2014 tentang Pemerintahan Daerah

Peraturan Wali Kota Palembang No. 14 Tahun 2019 tentang Pelaksanaan Kegiatan Gotong Royong.

\section{Penelitian Terdahulu}

Pebriyanti, Deby. 2017. “Implementasi Kebijakan Gotong Royong dalam Membangun Tongkonan di Desa Gendang Batu Kecamatan Gandang Batu Silanan Tana Toraja".(Tesis)

Okta, Lia. 2016. "Implementasi Pemahaman dan Sikap Pemuda terhadap Nilai Gotong Royong Untuk Pembangunan di Desa Semarang Jaya Kecamatan Air Hitam Kabupaten Lampung Barat".(Tesis)

Aryana Yoga, Miftah. 2016."Implementasi Kebijakan Gotong Royong dan Peduli Sosial pada Tradisi Nyadran". 